\title{
28. CLAY PETROLOGY OF MUDSTONES, LEG 18, DEEP SEA DRILLING PROJECT
}

\author{
John B. Hayes, Denver Research Center, Marathon Oil Company, Littleton, Colorado
}

\begin{abstract}
Clay minerals in mudstones from Leg 18 drilling sites offshore of Oregon and in the Gulf of Alaska have potential value for interpreting diagenetic history, provenance, sediment dispersal mechanisms, and relative movements of lithospheric plates. Clay mineral suites from both regions are similar to most from the Cenozoic of the northeast Pacific. They contain detrital, terrigenous chlorite, mica, and vermiculite. Mixed-layer clays are also abundant; these can either be weathering products of igneous and metamorphic minerals and volcanic debris, or submarine alteration products of volcanic material of continental or oceanic origin.

This question was asked about both regions: do crumpled mudstones at the continental margin represent trench fill which was deeply buried in the subduction zone and subsequently folded and uplifted against the continental slope? If so, the clay minerals may have undergone diagenetic reactions as a result of burial. In fact, there is no such evidence in the nature of mixed-layer clays progressively deeper in any hole examined to suggest diagenetic clay alteration of the type observed in Cenozoic shales of the Gulf of Mexico region. However, this does not rule out the possibility of the mudstones once being more deeply buried than they are now; it simply means that temperatures were not great enough to cause noticeable clay diagenesis.

The Columbia River and the Rogue River have delivered in the Pleistocene, and are delivering today, different clay mineral assemblages to the Oregon margin. These differences are related to rock types, climates, and weathering reactions in the respective drainage basins. These clay mineral differences between provenances persist and may even be enhanced as fine-grained sediments are carried several miles away from river mouths. This raises the possibility of using clay minerals for provenance recognition. Because clays tend to remain suspended longer than sands and are more widely dispersed in the oceans accordingly, many factors of sediment transport and dispersal need further evaluation before clay minerals have the same potential for determining provenance as have heavy minerals.

Clay-mineral stratigraphy at two sites (174 offshore of Oregon and 178 on Aleutian Abyssal Plain) on oceanic lithospheric plates can be interpreted to mean ever greater influence of terrestrial sedimentation upward through time. In other words, oceanic and continental plates moved closer together through time as the oceanic plate was swallowed in the subduction zone at the continental margin. Site 178 shows this particularly well, with Early Miocene clay suites being nearly pure mixed-layer clay of probable submarine volcanic origin, followed by ever increasing amounts of detrital, well crystallized, terrigenous mica and chlorite upward through the late Pleistocene.
\end{abstract}

\section{INTRODUCTION}

Is it possible that detailed study of clay minerals can shed light on processes taking place in subduction zones? Specifically, is there clay-mineral diagenetic evidence in mudstones for deep burial and subsequent uplift of trench sediments at Sites 175 and 181 on the continental slope? Clays from adjacent abyssal plain, trench, and continental shelf sites were examined for comparison. The sites fall into two somewhat analogous groups: (1) Sites 174, 175, and 176 offshore of Oregon; and (2) Sites 178, 180, and 181 in the Gulf of Alaska. In addition to the matter of burial 
diagenesis, the clay minerals can be used to make correlations, to suggest relative lithospheric plate motions with time, and, with further study, have the potential to indicate provenance. Because these interpretations depend on subtle but consistent details of clay mineralogy, techniques for analyzing the X-ray diffraction data upon which this report is based must be explained.

\section{METHODS}

\section{Sample Preparation}

Leg 18 mudstones and supplementary samples from offshore Oregon and the Rogue River were subjected to chemical pretreatments outlined by Jackson (1956, Chapter 2) and used by Duncan et al. (1970) in their study of offshore-Oregon clay minerals. The clay minerals $(<2 \mu$ e.s.d.) were separated by centrifugation, $\mathrm{Mg}$-saturated, and $\mathrm{X}$-rayed before and after solvation with ethylene glycol vapor. Additionally, some samples were K-saturated and $\mathrm{X}$-rayed to test the nature of vermiculitic and montmorillonitic mixed-layer minerals. Samples were heated to $525^{\circ} \mathrm{C}$ for the same purpose, as well as to test for presence of chlorite. A few samples were boiled in $1 N \mathrm{HC} 1$, which dissolved chlorite and left kaolinite unaffected. Random powder film patterns taken with $\mathrm{Fe} K_{\alpha}$ radiation were used to determine mica and chlorite polytypes and to check 060 spacing of dioctahedral versus trioctahedral clay minerals.

\section{Clay Mineral Identification}

Only minor variations were found in the nature of individual clay minerals over the entire study area, though relative amounts of these minerals are different from sample to sample. Figures 1 and 2 show typical clay mineral suites, one from Oregon and one from Alaska, and the criteria used to identify and characterize the various clay minerals.

Chlorite is recognized by a series of $00 \ell$ reflections based on 14.2- $\AA$ periodicity (Figure 1a); 002 and 004 typically are sharp and intense, whereas 001, 003, and 005 are medium to weak, respectively, and somewhat broadened. Chlorite is unaffected by ethylene glycol and K-saturation, but it dissolves in $\mathrm{HC1}$. After heating to $525^{\circ} \mathrm{C}, 001$ is greatly intensified, shifts to $13.8-\AA$, and order reflections disappear. Chlorites in Leg 18 mudstones are trioctahedral $\mathrm{Fe}-\mathrm{Mg}$ varieties, and are tentatively identified as the IIb polytype (Hayes, 1970).

Direct observation of 14.2- $\AA$-periodicity vermiculite as a separate phase is prevented by chlorite peaks in the same positions, but its presence is demonstrated by the effects of $\mathrm{K}$-saturation. The intensity of the $10-\AA$ peak is much greater relative to the $7-\AA$ and $14-\AA$ peak intensities after K-saturation (e.g., Figure 1b) than before (Figure 1a). Further, ethylene glycol solvation of the K-saturated material (Figure 1c) does not restore the original relative intensities. This suggests irreversible collapse of $14-\AA$ layers to $10-\AA$ spacing by $\mathrm{K}$-fixation, a defining property of vermiculite. This vermiculite is very likely trioctahedral, but the presence of trioctahedral chlorite prevents positive recognition. Absence of mixed-layer chlorite-vermiculite is demonstrated by the fact that no obvious peak appears upon heating to $525^{\circ} \mathrm{C}$, intermediate between 001 chlorite

\section{TYPICAL OFFSHORE OREGON CLAY MINERAL SUITE}

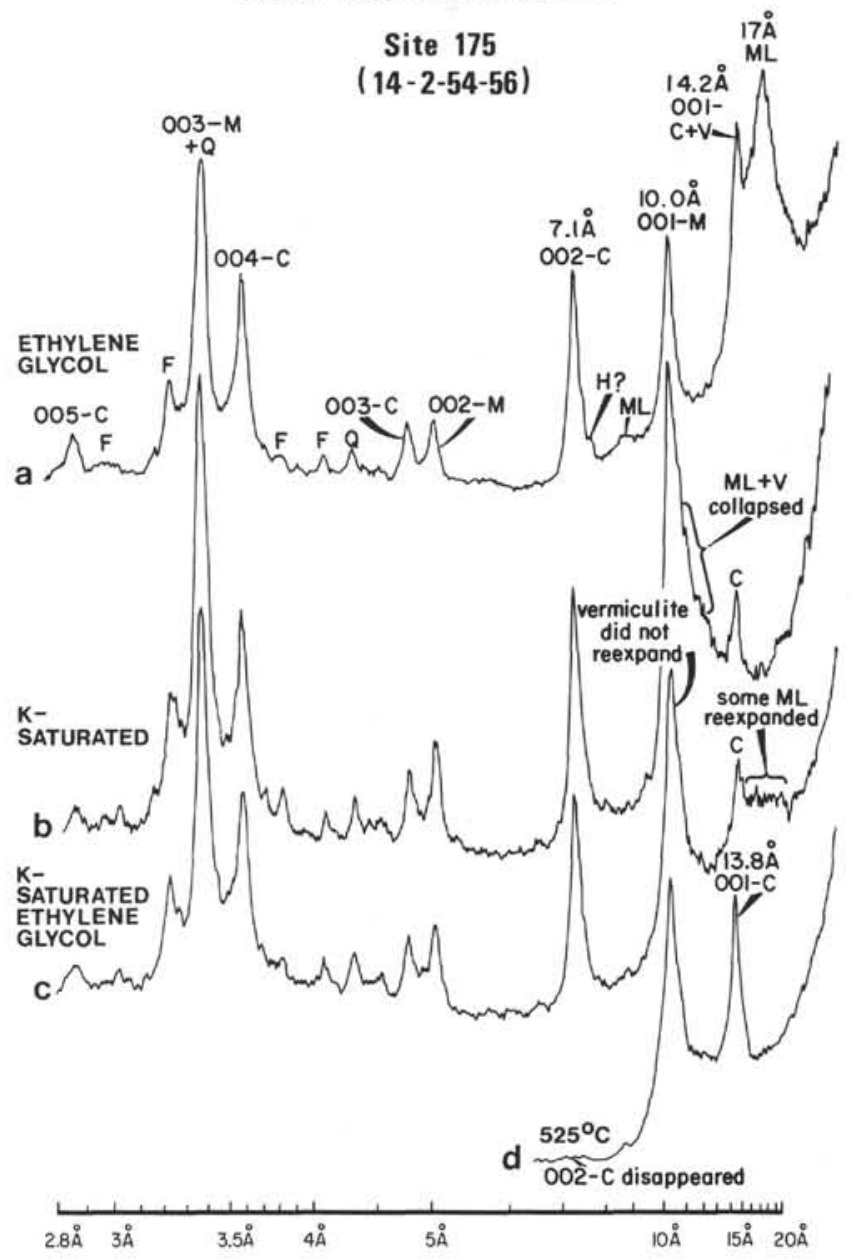

Figure 1. X-ray diffraction patterns of a typical offshore Oregon clay mineral suite. Mineral abbreviations for this and subsequent figures: $\mathrm{C}=$ chlorite; $\mathrm{M}=$ mica; $\mathrm{V}=$ vermiculite; $\mathrm{ML}=$ mixed-layer mica-montmorillonite; $\mathrm{H}=$ halloysite $; \mathrm{Q}=$ quartz; $\mathrm{F}=$ feldspars; $\mathrm{A}=$ amphibole; $\mathrm{CL}=$ clinoptilolite.

at $13.8-\AA$ and 001 of mica, and the collapsed vermiculite and collapsed mixed-layer clays combined at $10.0-\AA$ (Figure 1d).

Mica (or illite) as a discrete phase is recognized by a well-defined $10.0-\AA$ peak, weak 002 peak at $5.0-\AA$, and strong 003 at $3.33-\AA$ (Figure 1a). It is virtually unaffected by solvation, $\mathrm{K}$-saturation, heating, or $\mathrm{HC} 1$ treatment; but $10.0-\AA$ intensity increases upon heating or $\mathrm{K}$-saturation because other minerals collapse to $10.0-\AA$ unit spacing. The mica of Leg 18 mudstones is dioctahedral, aluminuous, muscovite-like variety, and is the $2 \mathrm{M}_{1}$ polytype.

My interpretation of clay which gives a broad $17-\AA$ peak with ethylene glycol (Figure 1a) departs from DSDP convention, and from interpretations published by many marine geologists. Whereas this clay has been called montmorillonite routinely, it is more properly called random mixed-layer mica-montmorillonite; it has variable but small amounts of vermiculite-like layers randomly 


\section{TYPICAL GULF OF ALASKA CLAY MINERAL SUITE}

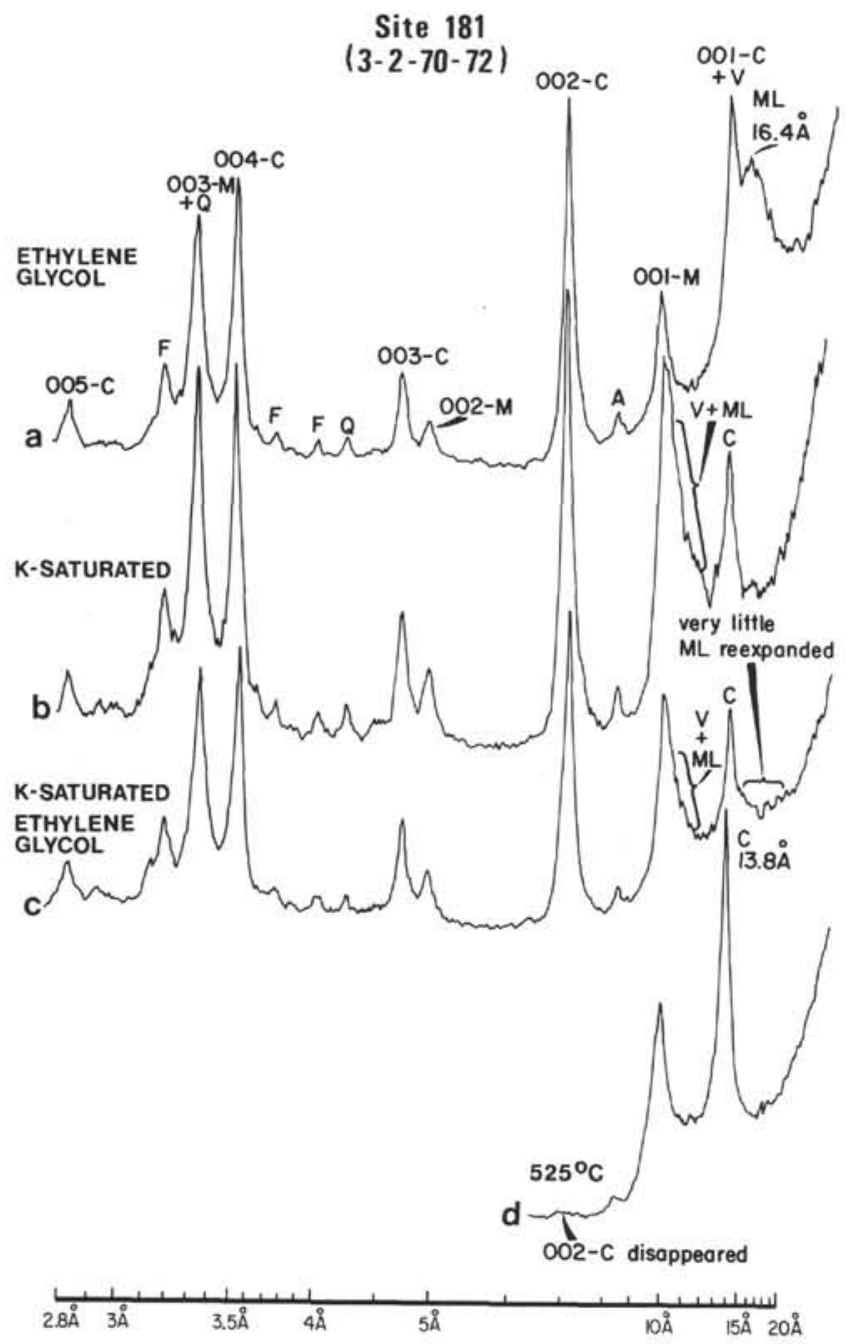

Figure 2. X-ray diffraction patterns of a typical Gulf of Alaska clay mineral suite.

interstratified with the other two layer types. This mixed-layer (ML for short) clay is dioctahedral, aluminous, and shows variation in the relative proportions of layer types. Reynolds and Hower (1970) showed that pure montmorillonite with no mixed-layering has a $17-\AA$ peak, but so does mixed-layer mica-montmorillonite, with up to 50 or 60 percent non-expansible mica layers. With increasing mica layers, intensity of the $17-\AA$ peak decreases, and the valley-to-peak ratio illustrated by Biscaye (1965, p. 806 , fig. 1) decreases, but the peak remains at $17-\AA$. Therefore, $17-\AA$ clay is not necessarily pure montmorillonite, and actually is not in most sediments and sedimentary rocks. Figure 1 of Biscaye (1965) could just as well be interpreted as showing increasing mica-layer content according to the criteria of Reynolds and Hower (1970), rather than as indicating decreasing "crystallinity", as Biscaye suggested. Composition of ML clay is determined by spacing of hybrid 002 mica/003 montmorillonite, which ranges between end-member limits. Table 1 shows spacing of this hybrid peak and corresponding percentage of mica layers; this peak is very weak and unresolvable in some samples. I disregarded the few percent of vermiculite-like layers in this analysis; they certainly will modify spacing and intensities somewhat. However, the purpose in assessing ML composition is to show only relative compositional trends, so no real harm is done by ignoring the vermiculitic component quantitatively at this point.

However, there are consistent and interpretable differences in the ML clays from Leg 18 caused by the vermiculitic component, which will be described later. The vermiculite-like layers in the ML clay are different from the discrete trioctahedral vermiculite described before, in that they have compositions and properties intermediate between dioctahedral mica and montmorillonite. Evidences for such vermiculitic layers include the following: (a) ethylene glycol does not swell the ML clay to $17 \AA$ in every sample (e.g., Figure $2 \mathrm{a}$ ), but only to $16.4 \AA$ or so; this means that a few layers with spacing between $10 \AA$ and $17 \AA$ are preventing formation of fully expanded $17-\AA$ spacing; and (b) collapse of the $17-\AA$ peak to between 10 and $11 \AA$ with $\mathrm{K}$-saturation (Figures $1 \mathrm{~b}$ and $2 \mathrm{~b}$ ), and minimal reexpansion with ethylene glycol (Figure 2c) indicate many expansible layers have fairly high, vermiculite-like net negative charge, intermediate between mica and montmorillonite charges.

Mere traces of kaolinite were found in a few samples from which chlorite had been removed by hot $\mathrm{HC} 1$, but no consistent distribution pattern emerged. Dehydrated halloysite appears in certain modern Rogue River stream sediments. It is recognized by first- and second-order basal reflections at $7.22 \AA$ and $3.63 \AA$, respectively, which are distinctly separated from adjacent chlorite peaks. Traces of probable halloysite were recognized in certain Leg 18 samples from offshore Oregon (e.g., Figure 1a).

Other minerals in the $<2 \mu$ clay suites include quartz; feldspars, mostly sodic plagioclase; amphiboles, identified by a peak at about $8.5 \AA$ (Figure $2 \mathrm{a}$ ); and clinoptilolite, Quar recognized by a sharp peak at $9.0 \AA$ (Figure $4 d$ ).

\section{Quantitative Mineralogical Analysis}

Only a crude and rapid technique for measuring relative proportions of the four major clay minerals (chlorite, vermiculite, mica, and $17-\AA$ mixed-layer clay) was used, because no very accurate method for doing so has been devised, and, with few exceptions, clay suites reported herein are so similar that slight differences in mineral content would be difficult to interpret even if they could be measured precisely. Briefly, I measured 7, 10, 14, and $17 \AA$ peak heights above horizontally projected background level, calculated ratios of $14 \AA / 10 \AA, 17 \AA /(3 \times 10 \AA)$, and $10 \AA / 10 \AA$ (always 1 ), added the ratios, and normalized to 100 percent. There is a problem estimating relative proportions of chlorite and vermiculite, because their basal reflections coincide. A quick method is to measure the $7 \AA / 14 \AA$ peak-height ratio, overlooking the probable intensification of the $14-\AA$ peak because of its proximity to the $17-\AA$ ML peak. I assumed this ratio to be 0.2 for pure vermiculite and 2.0 for pure chlorite. A straight line graph between these two points on semi-logarithmic paper gave the per cent chlorite from measured ratios, all of which fell between the assumed end-member limits. Results are shown 
TABLE 1

Mixed-Layer Clay Compositions of Leg 18 Mudstones and Related Sediments

\begin{tabular}{|c|c|c|c|c|c|}
\hline Sample & $\begin{array}{l}\text { Approx. } \\
\text { Depth (m) }\end{array}$ & Age & $\begin{array}{c}\text { Spacing }(\AA) \\
002_{10 \AA} / 003_{17} \AA\end{array}$ & $\begin{array}{l}\text { Percent } \\
\text { Mica-like } \\
\text { Layers }\end{array}$ & Comments \\
\hline $174 \mathrm{~A}-2-5(100-102)$ & 44.5 & Late Pleistocene & 5.56 & 26 & \multirow{10}{*}{$\begin{array}{l}284 \mathrm{~m} . \\
\text { base of fan }\end{array}$} \\
\hline $174 A-8-2(96-98)$ & 97.0 & Late Pleistocene & 5.58 & 20 & \\
\hline $174 \mathrm{~A}-11-2(127-129)$ & 126.0 & Late Pleistocene & 5.55 & 28 & \\
\hline $174 \mathrm{~A}-29-2(20-22)$ & 296.5 & Late Pleistocene & 5.53 & 30 & \\
\hline $174 \mathrm{~A}-33-2(67-69)$ & 344.0 & Late Pleistocene & 5.55 & 28 & \\
\hline $174 \mathrm{~A}-35-1(80-82)$ & 409.0 & Early Pleistocene & 5.51 & 35 & \\
\hline $174 A-36-1(34-36)$ & 446.5 & Pliocene & 5.56 & 26 & \\
\hline $174 \mathrm{~A}-37-1(33-35)$ & 504.0 & Pliocene & 5.56 & 26 & \\
\hline $174 \mathrm{~A}-39-3(89-91)$ & 753.5 & Pliocene & 5.61 & 15 & \\
\hline $174 \mathrm{~A}-40-1(144-146)$ & 761.0 & Pliocene & 5.56 & 26 & \\
\hline $175-3-3(50-52)$ & 18.5 & Late Pleistocene & 5.50 & 37 & \multirow{6}{*}{$\begin{array}{l}120 \mathrm{~m} . \\
\text { lithologic break }\end{array}$} \\
\hline $175-9-2(52-54)$ & 73.5 & Late Pleistocene & 5.55 & 28 & \\
\hline $175-13-2(60-62)$ & 111.5 & Late Pleistocene & 5.53 & 30 & \\
\hline $175-14-2(54-56)$ & 121.0 & Late Pleistocene & 5.55 & 28 & \\
\hline $175-18-1(51-53)$ & 158.0 & Early Pleistocene & 5.52 & 33 & \\
\hline $175-21-2(93-95)$ & 188.0 & Early Pleistocene & 5.55 & 28 & \\
\hline $176-1-1(136-138)$ & 1.0 & Holocene & 5.55 & 28 & \multirow{6}{*}{$\begin{array}{l}\text { Mouth of Astoria } \\
\text { Canyon } \\
\text { Interglacial }\end{array}$} \\
\hline $176-3-3(14-16)$ & 18.5 & Late Pleistocene & $a_{-}$ & - & \\
\hline $176-5-3(41-43)$ & 35.0 & Late Pleistocene & 5.56 & 26 & \\
\hline $6502-\mathrm{PC}^{\mathrm{b}}$ & $305-307.5 \mathrm{~cm}$ & Pleistocene & 5.56 & 26 & \\
\hline $6509-1-7^{b}$ & $50-52.5 \mathrm{~cm}$ & Holocene & - & - & \\
\hline $6509-1-7^{b}$ & $205-207.5 \mathrm{~cm}$ & Pleistocene & 5.58 & 20 & \\
\hline $178-4-2(55-57)$ & 26.0 & Late Pleistocene & - & - & \\
\hline $178-20-2(100-102)$ & 170.5 & Early? Pleistocene & - & - & $270 \mathrm{~m}$. \\
\hline $178-32-1(14-15)$ & 307.5 & Pliocene & - & - & lithologic break \\
\hline $178-44-2(90-92)$ & 458.0 & Middle Miocene & 5.49 & 38 & $742 \mathrm{~m}$. \\
\hline $178-54-4(90-92)$ & 747.5 & Early Miocene & 5.60 & 17 & lithologic break \\
\hline $178-57-1(125-127)$ & 769.5 & Early Miocene? & 5.55 & 28 & Clay shale \\
\hline $180-6-1(126-128)$ & 49.0 & Holocene & - & - & Trace amphibole \\
\hline $180-12-1(80-82)$ & 148.5 & Holocene & - & - & Trace amphibole \\
\hline $180-19-2(71-73)$ & 348.5 & Sangamon & - & - & Trace amphibole \\
\hline $180-24-2(56-58)$ & 453.5 & Illinoian & - & - & Trace amphibole \\
\hline $181-3-2(70-72)$ & 20.5 & Holocene & - & - & Trace amphibole \\
\hline $181-8-4(85-87)$ & 71.0 & Pleistocene & - & - & Trace amphibole \\
\hline $181-15-2(85-87)$ & 134.5 & Pleistocene & - & - & Trace amphibole \\
\hline $181-18-2(60-62)$ & 163.0 & Pleistocene & - & - & Trace amphibole \\
\hline $181-18-4(40-42)$ & 166.0 & Pleistocene & - & - & $169 \mathrm{~m}$. \\
\hline $181-19-1(110-115)$ & 170.0 & Pleistocene & 5.50 & 37 & lithologic break \\
\hline $181-20-1(0-5)$ & 177.0 & Pleistocene & 5.51 & 35 & No amphibole \\
\hline $181-22-1(125-132)$ & 197.0 & ? & 5.52 & 33 & No amphibole \\
\hline $181-23-1(142-144)$ & 207.0 & ? & - & - & No amphibole \\
\hline $181-25-2(15-20)$ & 226.5 & $?$ & - & - & No amphibole \\
\hline $181-30-1(50-55)$ & 361.0 & $?$ & 5.50 & 37 & No amphibole \\
\hline
\end{tabular}

${ }^{a}$ Hybrid peak unresolvable, either because $17 \AA$ clay is diluted by other components, or because the mixed-layer clay has appreciable vermiculite-like layers, and does not expand to full $17 \AA$, causing hybrid peak to shift closer to $5.0 \AA$ mica peak, from which it cannot be resolved.

${ }^{\mathrm{b}}$ Columbia River-derived clays, Oregon State University.

in Table 2. As noted before, height of $17-\AA$ peak is related to composition as well as to amount of mixed-layer clay. However, because most measurable mixed-layer compositions are similar, the compositional influence on $17-\AA$ peak height was disregarded.

\section{ORIGIN OF CLAY MINERALS}

Most of the clay minerals in Cenozoic mudstones from Leg 18 are probably detrital, derived from weathering and erosion of the continents. They were influenced very little by interaction with sea water (halmyrolysis), and not altered perceptibly after burial (diagenesis). The main exceptions to detrital origin are highly expansible ML clays near the bottom of the penetrated sedimentary section at Sites 174 and 178, and clinoptilolite at Site 174.

Clay-size $\mathrm{II} b$ chlorite and $2 \mathrm{M}_{1}$ mica in unmetamorphosed sediments and sedimentary rocks can be interpreted as detrital (Hayes, 1970). The IIb and $2 \mathrm{M}_{1}$ polytypes form at elevated temperatures, and are the common polytypes in igneous and metamorphic rocks. If the $\mathrm{II} b$ and $2 \mathrm{M}_{1}$ structures can survive weathering and erosion, they can be deposited as detrital components of fine-grained sediment. If sediment source areas containing 
TABLE 2

Clay Mineral Compositions $(<2 \mu)$ of Leg 18 Mudstones and Related Sediments

\begin{tabular}{|c|c|c|c|c|c|c|c|}
\hline Sample & $\begin{array}{l}\text { Approximate } \\
\text { Depth }(\mathrm{m})\end{array}$ & Age & $\begin{array}{c}\% \text { 17-A } \\
\text { Mixed- } \\
\text { layer }\end{array}$ & $\begin{array}{l}\% 14-\mathrm{A} \\
\text { verm. }\end{array}$ & $\begin{array}{l}\% 14-A \\
\text { chlorite }\end{array}$ & $\begin{array}{l}\% 10-\mathrm{A} \\
\text { mica }\end{array}$ & Comments \\
\hline $174 \mathrm{~A}-2-5(100-102)$ & 44.5 & Late Pleistocene & 27 & 30 & 20 & 23 & \multirow{10}{*}{$\begin{array}{l}284 \mathrm{~m} \text {. } \\
\text { base of fan }\end{array}$} \\
\hline $174 \mathrm{~A}-8-2(96-98)$ & 97.0 & Late Pleistocene & 19 & 31 & 25 & 25 & \\
\hline $174 \mathrm{~A}-11-2(127-129)$ & 126.0 & Late Pleistocene & 21 & 22 & 27 & 30 & \\
\hline $174 \mathrm{~A}-29-2(20-22)$ & 296.5 & Late Pleistocene & 20 & 24 & 26 & 30 & \\
\hline $174 \mathrm{~A}-33-2(67-69)$ & 344.0 & Late Pleistocene & 20 & 33 & 21 & 26 & \\
\hline $174 A-35-1(80-82)$ & 409.0 & Early Pleistocene & 17 & 24 & 24 & 35 & \\
\hline $174 \mathrm{~A}-36-1(34-36)$ & 446.5 & Pliocene & 32 & 31 & 15 & 22 & \\
\hline $174 \mathrm{~A}-37-1(33-35)$ & 504.0 & Pliocene & 26 & 35 & 16 & 23 & \\
\hline $174 \mathrm{~A}-39-3(89-91)$ & 753.5 & Pliocene & 35 & 31 & 15 & 19 & \\
\hline $174 \mathrm{~A}-40-1(144-146)$ & 761.0 & Pliocene & 32 & 28 & 23 & 17 & \\
\hline $175-3-3(50-52)$ & 18.5 & Late Pleistocene & 24 & 30 & 31 & 26 & \multirow{6}{*}{$\begin{array}{l}120 \mathrm{~m} \text {. } \\
\text { lithologic break }\end{array}$} \\
\hline $175-9-2(52-54)$ & 73.5 & Late Pleistocene & 20 & 24 & 30 & 26 & \\
\hline $175-13-2(60-62)$ & 111.5 & Late Pleistocene & 27 & 18 & 30 & 25 & \\
\hline $175-14-2(54-56)$ & 121.0 & Late Pleistocene & 18 & 26 & 23 & 33 & \\
\hline $175-18-1(51-53)$ & 158.0 & Early Pleistocene & 16 & 27 & 30 & 27 & \\
\hline $175-21-2(93-95)$ & 188.0 & Early Pleistocene & 11 & 28 & 23 & 38 & \\
\hline $176-1-1(136-138)$ & 1.0 & Holocene & 32 & 27 & 20 & 21 & \multirow{6}{*}{$\begin{array}{l}\text { Mouth of Astoria } \\
\text { Canyon } \\
\text { Interglacial }\end{array}$} \\
\hline $176-3-3(14-16)$ & 18.5 & Late Pleistocene & 9 & 32 & 22 & 37 & \\
\hline $176-5-3(41-43)$ & 35.0 & Late Pleistocene & 29 & 26 & 23 & 22 & \\
\hline $6502-\mathrm{PC}^{\mathrm{a}}$ & $305-307.5 \mathrm{~cm}$ & Pleistocene & 31 & 35 & 17 & 17 & \\
\hline $6509-1-7^{\mathrm{a}}$ & $50-52.5 \mathrm{~cm}$ & Holocene & 24 & 21 & 31 & 24 & \\
\hline $6509-1-7^{a}$ & $205-207.5 \mathrm{~cm}$ & Pleistocene & 18 & 36 & 26 & 20 & \\
\hline $178-4-2(55-57)$ & 26.0 & Late Pleistocene & 12 & 10 & 45 & 33 & \multirow{6}{*}{$\begin{array}{l}270 \mathrm{~m} . \\
\text { lithologic break } \\
742 \mathrm{~m} \text {. } \\
\text { lithologic break } \\
\text { Clay shale }\end{array}$} \\
\hline $178-20-2(100-102)$ & 170.5 & Early? Pleistocene & 16 & 12 & 41 & 31 & \\
\hline $178-31-1(14-15)$ & 307.5 & Pliocene & 20 & 27 & 31 & 22 & \\
\hline $178-44-2(90-92)$ & 458.0 & Middle Miocene & 31 & 47 & 6 & 16 & \\
\hline $178-54-4(90-92)$ & 747.5 & Early Miocene & 89 & 0 & 5 & 6 & \\
\hline $178-57-1(125-127)$ & 769.5 & Early Miocene? & 91 & 0 & 4 & 5 & \\
\hline $180-6-1(126-128)$ & 49.0 & Holocene & 14 & 13 & 47 & 26 & Trace amphibole \\
\hline $180-12-1(80-82)$ & 148.5 & Holocene? & 11 & 16 & 44 & 29 & Trace amphibole \\
\hline $180-19-2(71-73)$ & 348.5 & Sangamon & 12 & 10 & 49 & 29 & Trace amphibole \\
\hline $180-24-2(56-58)$ & 453.5 & Illinoian & 13 & 12 & 47 & 28 & Trace amphibole \\
\hline $181-3-2(70-72)$ & 20.5 & Holocene & 16 & 18 & 39 & 27 & Trace amphibole \\
\hline $181-8-4(85-87)$ & 71.0 & Pleistocene & 12 & 9 & 47 & 32 & Trace amphibole \\
\hline $181-15-2(85-87)$ & 134.5 & Pleistocene & 9 & 19 & 45 & 27 & Trace amphibole \\
\hline $181-18-2(60-62)$ & 163.0 & Pleistocene & 12 & 22 & 42 & 24 & Trace amphibole \\
\hline $181-18-4(40-42)$ & 166.0 & Pleistocene & 13 & 14 & 45 & 28 & $169 \mathrm{~m}$. \\
\hline $181-19-1(110-115)$ & 170.0 & Pleistocene & 15 & 10 & 46 & 29 & lithologic break \\
\hline $181-20-1(0-5)$ & 177.0 & Pleistocene & 15 & 10 & 44 & 31 & No amphibole \\
\hline $181-22-1(125-132)$ & 197.0 & $?$ & 13 & 9 & 47 & 31 & No amphibole \\
\hline $181-23-1(142-144)$ & 107.0 & ? & 18 & 11 & 42 & 29 & No amphibole \\
\hline $181-25-2(15-20)$ & 226.5 & ? & 15 & 11 & 46 & 28 & No amphibole \\
\hline $181-30-1(50-55)$ & 361.0 & ? & 15 & 10 & 44 & 31 & No amphibole \\
\hline
\end{tabular}

${ }^{\mathrm{a} C}$ Columbia River-derived clays, Oregon State University.

chlorite- and mica-rich rocks have high relief, high precipitation and runoff, and short distance of transport to the sea, considerable detrital chlorite and mica can be moved. These conditions are met in Oregon and Alaska continental borderlands which supplied the Leg 18 sediments. For example, certain tributaries of the Rogue River draining the metamorphic rocks of the Klamath Mountains in southwestern Oregon are heavily charged with $\mathrm{Il} b$ chlorite and $2 \mathrm{M}_{1}$ mica (Figure $3 \mathrm{a}$ ). Glacial grinding of crystalline rocks produces abundant fine-grained silicate minerals, including chlorite and mica, as rock flour for delivery to sites of deposition. Glaciation was widespread through much of the time represented by the sediments studied, particularly in Alaska. Chlorite and mica together are even more abundant in the Gulf of Alaska samples than in those from offshore Oregon. Clay-size amphibole, an easily weathered mineral, in the Alaska-derived clays further suggests rock flour as an important sediment source.

In contrast to the little-weathered, well-crystallized chlorite and mica are the terrestrial weathering products, halloysite, kaolinite, vermiculite, and ML micamontmorillonite. These minerals, along with other kinds of intermediate mixed-layer clays, have been reported forming in soils of western Oregon (Robertson, 1963; Tidball, 1965; Chichester et al., 1969), mainly as weathering products of widespread, late Cenozoic volcanic ash, pumice, obsidian, 


\section{LATE PLEISTOCENE AND HOLOCENE CLAY MINERAL COMPOSITIONS OREGON CONTINENTAL MARGIN}

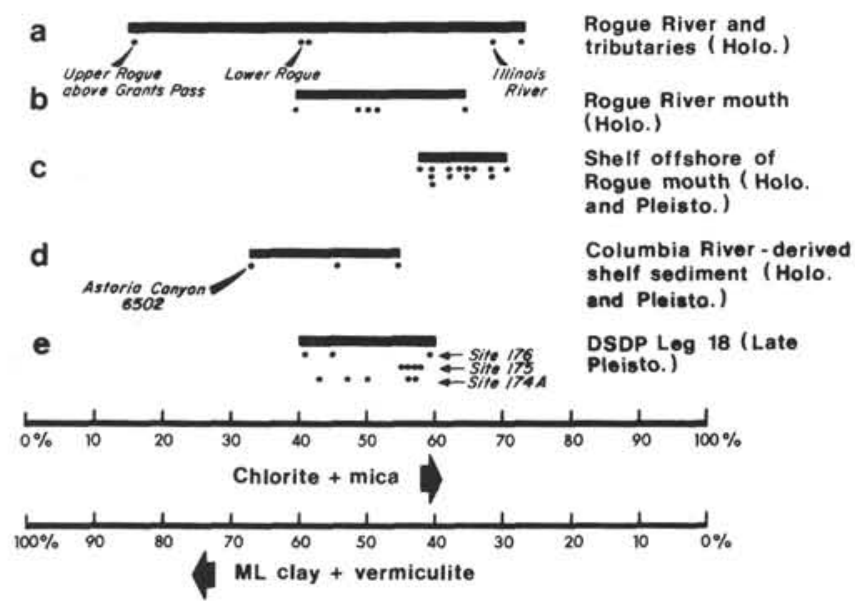

Figure 3. Late Pleistocene and Holocene clay mineral compositions of stream sediments and marine mudstones, Oregon continental margin.

lava flows, and cinder beds. But also, these various clays could form by weathering of plutonic rocks, metamorphosed sedimentary and volcanic rocks, and unmetamorphosed detrital rocks. Differences in climate, parent material, topography, and all other factors influencing weathering and soil formation are responsible for different soil clay assemblages from place to place; however, these minerals were apparently the major weathering products available for transport to the sea, where we now find them in marine mudstones of offshore Oregon. Some clay mineral products of weathering must also have been available from Alaska, but cold climate and widespread Quaternary glaciation retarded production of such relative to Oregon. In fact, Leg 18 mudstones in the Gulf of Alaska contain relatively less vermiculite and ML clay than those from offshore Oregon, and no detectable halloysite.

Determining the origin of ML clay in marine mudstones is a problem, because, unlike detrital chlorite, mica, halloysite, and vermiculite of terrestrial origin, ML clay could originate in the ocean basins as well as on land. That is, ML clay could be produced by reactions between sea water and oceanic volcanic matter erupted either above or below water (halmyrolysis). Or, halmyrolysis could produce ML clay by water reacting with rocks in submarine outcrops. For example, Rex (1967) reported montmorillonite with some chloritic mixed-layering to be an important submarine alteration product of basaltic glass in the Pacific. Siever and Kastner (1967, p. 274) wrote about montmorillonite in Mid-Atlantic Ridge sediments: "The simplest explanation is that well-crystallized montmorillonite is detritus from marine weathering of the nontronitic greenstones that crop out in the Median Valley, and that the poorly crystallized ones are low-temperature alteration products of recently deposited ash." Those authors' usage of the terms "well-crystallized" and "poorly crystallized" follows that of Biscaye (1965); as I have indicated, the "poorly crystallized" montmorillonite is most likely ML clay with considerable nonexpansible layers and lowintensity $17-\AA$ peak.

Not only can ML clay form on land or in the sea, but it can form from different parent materials. Because ML clay is intermediate between mica and montmorillonite, it could come from weathering of mica, or it could be produced by alteration of montmorillonite, which itself is a common alteration product of glassy volcanic material. So, we end up with at least four possible prediagenetic origins for ML clay in marine mudstones:

1) Terrestrial weathering of mica in igneous, metamorphic, and older detrital rocks, a process which has been demonstrated repeatedly in soils the world over;

2) Halmyrolysis ("submarine weathering") of relatively fresh mica (e.g., $2 \mathrm{M}_{1}$ mica in Leg 18 samples), a process invoked by Berry and Johns (1966), but which was probably inhibited for most of the Leg 18 clays because of rapid sedimentation rates;

3) Terrestrial weathering of glassy volcanic material and montmorillonite, a process which has produced abundant ML clay in pumice-derived soils of western Oregon (e.g. Chichester et al., 1969); and

4) Halmyrolysis of volcanic material and montmorillonite, a process demonstrated by $\operatorname{Rex}(1967)$ the parent material may be from oceanic volcanic activity, or it may be carried to the sea from terrestrial sources by winds and streams.

Obviously it would be important to distinguish the various sources and origins of ML mica-montmorillonite in a marine mudstone or through a stratigraphic section, but how is it done? Frankly, this study provides very few clues. I will demonstrate stratigraphically consistent trends and differences in the detailed nature of Leg 18 ML clays, especially in the vermiculitic layers. These differences probably are due to different origins of ML clay and not to different diagenetic histories. As a general rule, the ML clays with high-charge vermiculitic layers, those which do not expand to $17 \AA$ with ethylene glycol (Figure 2a), were probably derived from mica alteration; whereas the ML clays which do not have as many vermiculitic layers and expand to $17 \AA$ (Figure 1a) were produced by alteration of glass and montmorillonite. Weaver (1958) reviewed the literature and presented data which support this view. If subtle details of ML composition indeed have interpretive value, and these details have X-ray expression, representative X-ray diffraction traces should be published in papers describing marine clays.

\section{SITES 174, 175, 176 - OREGON CONTINENTAL MARGIN}

Clay minerals from these sites qualitatively and quantitatively resemble clays from the Oregon margin described in the literature (Duncan et al., 1970). Further, the clay suites from most of the Oregon Leg 18 samples are similar to one another (Table 2, Figure 3e). Each of the four principal clay minerals (chlorite, mica, vermiculite, and ML clay) makes up on average about 25 per cent of the typical clay suite. Interpretations using these data 
necessarily depend on subtle variations in amount and nature of the various minerals.

\section{Burial Diagenesis}

The bottom part of the sedimentary section drilled at Site 175 on the lower continental slope contains lower Pleistocene turbidites which appear to have been deposited in water deeper than at present (see Site 175 summary, this volume). One speculation is that this section represents trench fill which was rather deeply buried in the subduction zone and then uplifted and folded against the continental margin. If so, progressive clay mineral reactions during diagenesis might have occurred, which could be evidence for deeper burial. The principal premetamorphic clay reaction for this particular suite should be decreasing expansible layers of the $17-\AA \mathrm{ML}$ clay with increasing depth and temperature. This is analogous to the burial diagenetic reaction of ML clay described for Gulf of Mexico Cenozoic mudstones by Perry and Hower (1970). Ever increasing fixation of potassium with increasing depth and temperature causes expansible montmorillonite-like layers to collapse and become mica-like.

To answer the question, I cannot see any systematic changes in ML clay or in any other clay mineral with depth which can be ascribed to progressive diagenesis. Table 1 shows no consistent increase in percentage of mica layers with depth at any of the three Oregon sites. In fact, there is a slight decrease in percentage of mica layers toward the bottom of Hole $174 \mathrm{~A}$, just the reverse of the proposed diagenetic reaction. However, this reaction probably is not reversible, in the sense that a mixed-layer clay will not return to being more montmorillonitic upon uplift of mudstones unless it enters the zone of weathering. The offshore Oregon mudstones probably were never buried deeply enough to initiate mixed-layer diagenesis. In Gulf of Mexico sediments, montmorillonite-to-mica conversion does not begin until at least 2000 meters burial depth, according to Perry and Hower (1970), or between 1500 meters and 500 meters, according to Burst (1969). The present depth of burial of Sites 174,175, and 176 mudstones is much less than these minima (disregarding water depth, which is not important for burial diagenesis). Differences in geothermal gradient between the Gulf Coast and Offshore Oregon, differences in potassium supply, and differences in initial composition of mixed-layer clay (i.e., a few percent vermiculite-like layers in Oregon material) could influence the reaction and could make comparisons between the two areas less appropriate. Even so, I can confidently say that the Leg 18 Oregon clays were not buried to depths of 3000 or 4000 or 5000 meters or more. This neither proves nor disproves the idea of the sediments once being more deeply buried than now, but at least they were never deep enough nor hot enough for one of the lowest-temperature diagenetic clay reactions to be initiated.

\section{Provenance}

Different sediment source areas which contributed to Pleistocene and Holocene deposits of offshore Oregon have been recognized by heavy mineral suites (Duncan and Kulm, 1970; Scheidegger et al., 1971) and by composition of clay mineral suites (Duncan et al., 1970). The question naturally arose as to whether or not late Pleistocene and Holocene clay mineral suites at Sites 174, 175, and 176 can be ascribed to a parent drainage basin or particular provenance. If so, this might provide information on dispersal patterns and relative motions of lithospheric plates with time.

Because the same kinds of clay minerals appear in most samples, as Duncan et al. (1970) and this report have pointed out, provenance distinctions depend on relative amounts of individual clay minerals. Different methods of sample preparation, X-ray analysis, and quantitative interpretation in different laboratories yield results which are not comparable in detail. Therefore, I analyzed three sets of non-DSDP samples from the Oregon margin by the same methods used on Leg 18 clay suites for direct comparison. The samples were as follows: (1) ten bedload samples from the modern Rogue River in southwestern Oregon (some from the estuary were supplied by L. D. Kulm of Oregon State University, and some from upstream and major tributaries were collected by me) (Figure 3a-b); (2) thirteen Holocene and late Pleistocene mudstones from the continental shelf and slope at a maximum of 35 miles offshore of the Rogue River mouth, supplied by L. D. Kulm (Figure 3c); and (3) three Holocene and Pleistocene piston core samples of marine muds derived from the Columbia River drainage, supplied by L. D. Kulm (Figure 3d; Tables 1 and 2).

After percentages of the four clay minerals (Table 2) were plotted in various combinations on triangular graphs, it became apparent that the best discriminators are chlorite plus mica versus vermiculite plus mixed-layer $17-\AA$ clay, as shown on Figure 3. This makes sense, because these two pairs of minerals are apparently derived from distinctly different rock types and geologic settings, at least in the Pacific Northwest. Mica and chlorite, the well-crystallized, high-temperature $2 \mathrm{M}_{1}$ and II $b$ polytypes respectively, are derived from weathering and erosion of older shales and sandstones, plutonic igneous rocks, and low-rank metasediments and metavolcanics. On the other hand, mixed-layer clay comes mainly from devitrification and weathering of intermediate to basic volcanic material, and vermiculite is mainly the incipient weathering product of biotite so common in volcanic rocks. This genetic distinction is strikingly displayed by clays being carried today by the Rogue River (Figure 3a). The Rogue drainage basin above Grants Pass, Oregon, is mainly in Cascadian volcanic terrains; the Rogue heads near Crater Lake (Mt. Mazama). ML clay and vermiculite (plus halloysite which was not calculated) far outweigh chlorite and mica in the stream sediment. In contrast, downstream from Grants Pass the Rogue and major tributaries, such as the Applegate and Illinois rivers, are draining the metamorphosed Paleozoic and Mesozoic sedimentary and volcanic rocks of the Klamath Mountains. The tributaries are heavily charged with clay-size chlorite and mica, which dilute the soil-clay content of the main stream. Clay suites from near the mouth of the Rogue (Figure $3 \mathrm{~b}$ ) have intermediate compositions.

Rogue-derived late Pleistocene and Holocene clay suites on the adjacent continental shelf (Figure $3 \mathrm{c}$ ) fall into a tight compositional field with considerably more chlorite 
and mica than occurs in most of the river samples (Figure $3 \mathrm{a}-\mathrm{b})$. Apparently, once the clays entered the ocean, mineralogical segregation according to particle size and flocculation tendencies preferentially settled chlorite and mica, and left the typically very fine grained ML clay in suspension. An analogous situation might be in the Gulf of Mexico, where most stream-borne clay minerals settle around the margin of the basin, and montmorillonite or ML clay accumulates preferentially in the central part by very slow pelagic fallout (Pinsak and Murray, 1960). This interpretation presupposes that halmyrolysis and diagenesis have not influenced composition of clay mineral assemblages along the Oregon margin. I think this is true, because clay minerals carried by the Rogue River today are virtually identical in kind to Pleistocene and Holocene clay minerals deposited offshore of the Rogue. Also, clay mineral suites in the marine muds are very uniform in character from sample to sample, irrespective of time and place. Differences in relative amounts of clay minerals in Oregon marine muds must be due to rock and climate differences in source areas and to dispersal mecianisms. Duncan et al. (1970) reached that same conclusion.

Duncan et al. (1970) noted that modern deep-sea clays derived from the Columbia River drainage are richer in $17-\AA$ clay than are clays from other Pacific Northwest drainages, like the Rogue River, which they cited for its high chlorite content. The Rogue is representative of the several rivers draining the high-relief Klamath Mountains of southwest Oregon and northern California. Duncan et al. (1970) further observed that, in the Pleistocene, the Columbia delivered more mica and less ML clay than in the Holocene, but even in the Pleistocene, the Columbia suite was distinctive from Pleistocene clays from Oregon borderland sources of the Rogue type. This is borne out by my data, which show the three samples (Figure 3e) from Site 176 (about 35 miles from the Columbia mouth) and the three Columbia-derived muds (Figure 3d) to have more expansible $17-\AA$ and vermiculitic clays than the thirteen shelf-deposited muds derived from the Rogue (Figure 3c), whether Pleistocene or Holocene. Therefore, I conclude that distinctive clay mineral assemblages related to provenance have been and are being delivered to the sea along the Oregon margin, just as distinguishable heavy mineral suites are (Scheidegger et al., 1971). Further, these differences persist and may even be enhanced as the fine-grained sediments are carried several miles along the shelf.

This raises the possibility of using clay minerals for provenance recognition in sedimentary sections lacking sand. However, many factors need further evaluation before this can be done confidently; for example, effects of currents, waves, and turbidity currents on dispersal patterns along the Oregon margin; effects of fluctuating volcanic activity on supply and dispersal of ML clay and precursors; effects of Pleistocene glaciation on clay mineral content of streams, such as Duncan et al. (1970) demonstrated for the Columbia River; effects of Pleistocene sea-level lowering on stream gradients, weathering and erosion rates, and marine dispersal mechanisms. The late Pleistocene clay mineral suites at Sites 174 and 175 (Figure 3e), for example, have compositions intermediate ketween late Pleistocene suites of known Rogue source (Figure 3c) and known Columbia source (Figure 3d), Astoria Canyon sample). Does this mean that Pleistocene dispersal mechanisms moved Rogue River clays north to be mixed with southward-dispersed Columbia River clays? Is that proposal tenable, given what is known about currents and waves along the Oregon margin (see Spigai, 1971, p. 134-141, for summary)? Alternatively, could the near Rogue-like compositions of many Site 174 and 175 clay suites signal relative northward displacement of the Gorda-Juan de Fuca oceanic plate relative to the North American continent? I have answered the question of recognizing provenance with clay minerals in Oregon marine muds simply by asking further questions. I think more work needs to be done.

\section{Tectonic Implications}

One way to interpret the stratigraphic succession of clay minerals at Site 174 is to indicate ever closer approach of the oceanic Gorda-Juan de Fuca plate toward the North American continent through time. Consistent differences between Pliocene and Pleistocene clay suites suggest this. Some differences are as follows:

(1) The average amount of $17-\AA$ ML clay is greater in Pliocene samples (Core 36 and deeper) than in the Pleistocene, and amounts of mica and chlorite are correspondingly less (Table 2).

(2) Pliocene ML clay collapsed to only about $11 \AA$ with $\mathrm{K}$-saturation, and reexpanded with ethylene glycol to restore a crude $17-\AA$ peak (Figure $4 \mathrm{~d}-\mathrm{f}$ ); whereas Pleistocene ML clay collapsed much more with $\mathrm{K}$-saturation and did not reexpand as much with glycol (Figure 4a-c). I interpret this to mean that Pliocene ML clay contains mostly low-charge expansible layers, suggesting devitrification of volcanic glass (in sea water?). In contrast, Pleistocene mixed-layer clay contains some high-charge (vermiculite-like) expansible layers, suggestive of terrestrial alteration of micas.

(3) Pliocene ML clays have slightly fewer nonexpansible layers than those in the Pleistocene (Table 1).

(4) The Pliocene samples contain clinoptilolite, which decreases from Core 40 upward through Core 36. Biscaye (1965, p. 824) suggested that clinoptilolite (and heulandite?) in deep-sea sediments might be products of in situ alteration of volcanic debris. Rex (1972) stated that basaltic glass in deep-sea sediments usually alters to clinoptilolite or phillipsite plus montmorillonite.

These differences between Pliocene and Pleistocene clay suites suggest that, during the Pliocene, Site 174A was further removed from the influence of terrestrial sedimentation than in the Pleistocene and Holocene. Pliocene sediment was preferentially enriched in very fine grained ML clay, most of which was derived from halmy rolytic alteration of local submarine volcanic detritus. Terrigenous ML clay could also have been concentrated far offshore by differential settling of mica and chlorite closer to the continent, as in the Rogue River case. In the Pleistocene, relative plate motion moved Site 174 closer to the continental plate from which more terrigenous mica and chlorite were deposited. 


\section{NATURE OF MIXED - LAYER CLAY MINERALS, OFFSHORE OREGON}

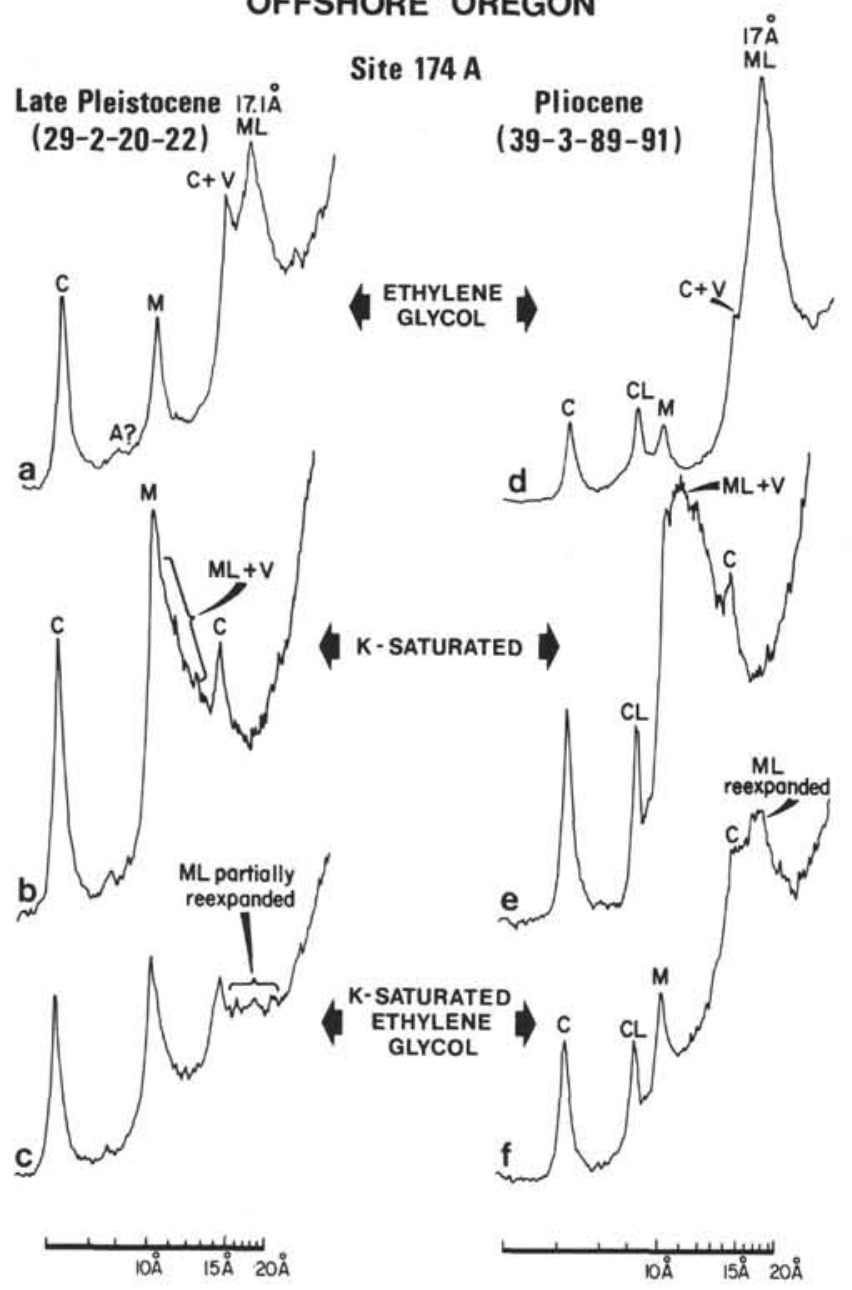

Figure 4. X-ray diffraction patterns of representative samples to show differences between Pliocene and Pleistocene mixed-layer clays at Site $174 \mathrm{~A}$.

\section{SITES $178,180,181-$ GULF OF ALASKA}

In general, clay mineral suites of mudstones from these three sites are very similar qualitatively and, with few exceptions, quantitatively. The Alaskan suites compare favorably with modern oceanic clays from the northeast Pacific (Griffin et al., 1968) and with clay minerals in mudstones from onshore Tertiary sections around the Gulf of Alaska (Bateman, 1967). Chlorite averages about 45 percent, mica about 30 percent, and vermiculite and ML clay each about 15 percent (Table 2). Figure 2 shows a typical Pleistocene clay suite from Site 181. Alaskan clays are slightly different, on the average, from offshore Oregon clays (Figure 1). The Alaskan suites have more chlorite than vermiculite, evidenced by the $7-\AA$ peak being more intense than the 14- $\AA$ peak. They have more chlorite and vermiculite, correspondingly less ML clay, and about the same mica content as the Oregon samples. Also, the Alaskan ML clays contain, on the average, more high-charge vermiculite-like layers than do the Oregon clays, judging from expansion to only about $16.4 \AA$ with ethylene glycol (Figure 2a) and behavior with K-saturation (Figure 2b-c).

Topographic, tectonic, and climatic conditions around the Gulf of Alaska during the Pleistocene and much of the Cenozoic are consistent with the detrital interpretation of clay minerals. High content of well-crystallized, hightemperature $2 \mathrm{M}_{1}$ mica and $\mathrm{II} b$ chlorite in Alaskan clay suites suggests rapid mechanical weathering and erosion and little chemical weathering in source areas. Glacial grinding of crystalline rocks to produce rock flour was an important process. Environments of deposition and burial diagenesis modified the clays little. Rates of deposition and burial were so great for Site 180 and 181 sediments (several hundred meters per million years) that the clays had little time to react significantly with sea water (halmyrolysis). If halmyrolysis did occur, I would expect it to have happened in places of slow terrestrial sedimentation, far from shore where local submarine volcanic debris accumulated and was altered to mixed-layer mica-montmorillonite.

\section{Deformed Mudstone-Site 181}

The initial question at Site 181 was essentially the same as for Site 175: is there clay-mineral evidence for deeper burial and subsequent uplift and folding of deep-sea mudstones against the continental margin? At 169 meters in Hole 181 is a puzzling lithologic break between soft Pleistocene mudstones above, and hard, deformed mudstones of unknown age below. Has the hard mudstone below been more deeply buried than it is now? My answer is also the same as for Site 175; there is no evidence to suggest that the rocks below 169 meters were buried deeply enough, a few thousand meters, to cause appreciable diagenetic alteration of mixed-layer clay. The mudstone may have been deeper than now, but no record of that was preserved in the mixed-layer clays, or, for that matter, in any of the other clay minerals.

At Site 181, there is a subtle difference between ML clays on either side of the 169-meter boundary, but it is opposite to the predicted effects of diagenesis. Table 1 shows measurements of ML composition below 169 meters from the hybrid $002 / 003$ peak. This peak is very poorly resolved from the adjacent $5-\AA 002$ peak of discrete mica, however. But for ML clays above 169 meters, no hybrid peak could be resolved, not even by solvating with glycerol instead of ethylene glycol. ML first-order peaks above and below 169 meters also are different. Figure 5b shows the ML peak above 169 meters as a poorly resolved, approximately $16-\AA$ shoulder on the $14-\AA$ peak. In contrast, Figure $5 \mathrm{c}$ shows a well-resolved peak at full $17-\AA$ spacing below 169 meters. I think the hybrid 002/003 and $17-\AA$ peaks are telling the same story-ML clay above 169 meters has some vermiculitic layers, whereas ML clay below 169 meters is essentially non-vermiculitic mica-montmorillonite. This subtle difference in ML clay above and below 169 meters is probably not caused by diagenesis, but rather is related to origin of the ML clays.

\section{Tectonic Implications of Site 178 Clay Minerals}

Clay mineral stratigraphy at Site 178 has essentially the same meaning as at Site 174, but covers a longer time span and a more complete compositional range. Figure 6 


\section{CLAY MINERALS AT SITES 180 AND181 GULF OF ALASKA}

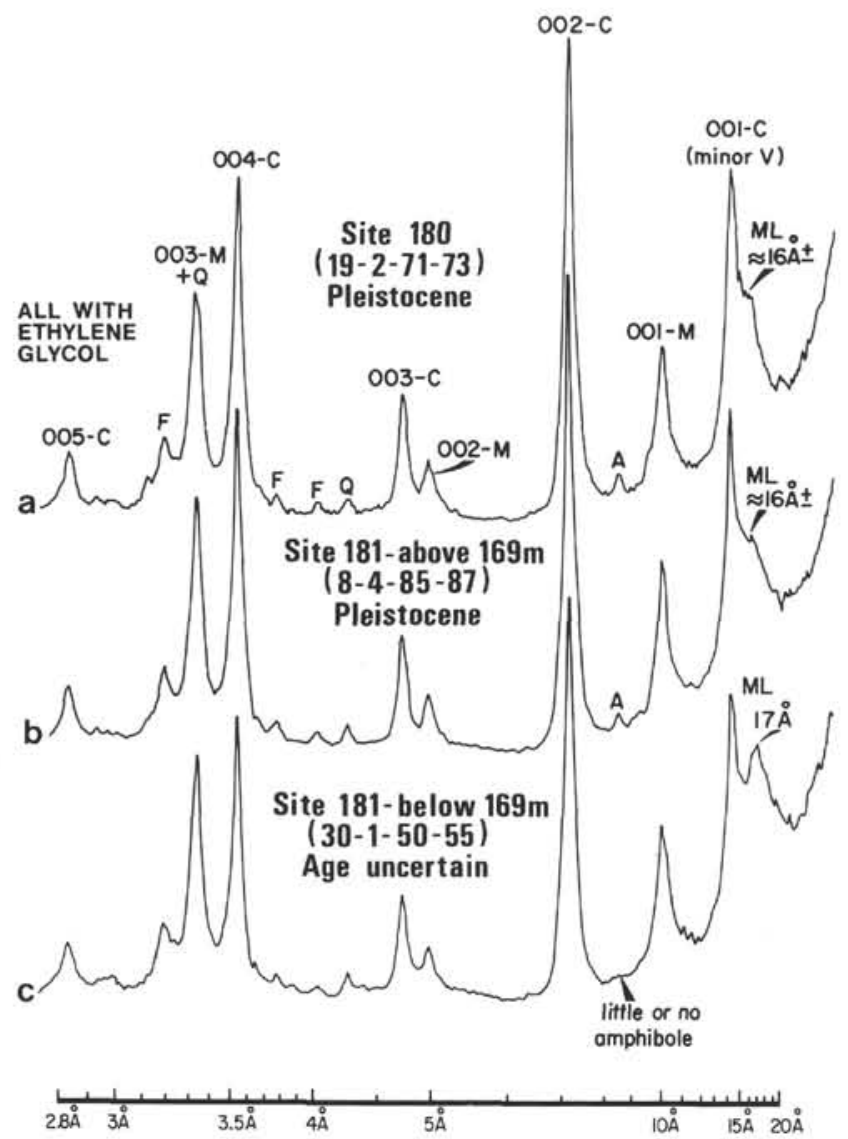

Figure 5. X-ray diffraction patterns to show differences between Pleistocene clay minerals at Sites 180 and 181, and clay minerals below $169 \mathrm{~m}$ at Site 181.

and Table 2 show that ML clay decreases in amount dramatically from the Miocene in the lower part of the hole up through the Pleistocene at the top, and that well-crystallized detrital mica and chlorite increase progressively upward. Further, the mixed-layer clay toward the bottom of the section appears to be non-vermiculitic, and the spacing of the hybrid $002 / 003$ peak indicates higher expansibility than further up the section (Table 1). Higher in the hole the mixed-layer clay becomes more and more vermiculitic, as evidenced by gradual shift of the peak toward $16 \AA$ and the unresolvable nature of the hybrid $002 / 003$. One possible interpretation of this dramatic upward change is that mixed-layer clay in the lower part of the section, which probably resulted from halmyrolysis of submarine volcanic debris, was diluted by ever increasing amounts of detrital, terrigenous mica, chlorite, and some terrigenous ML clay as Site 178 moved closer to the North American Plate with time. Also, Pleistocene glaciation probably contributed even more chlorite and mica, relative to other clay minerals, in the upper part of the section.

An alternative explanation for the relative decrease of ML clay upward at Site 178 is long-term decline of eruptive

\section{CLAY MINERAL STRATIGRAPHY AT SITE 178 GULF OF ALASKA}

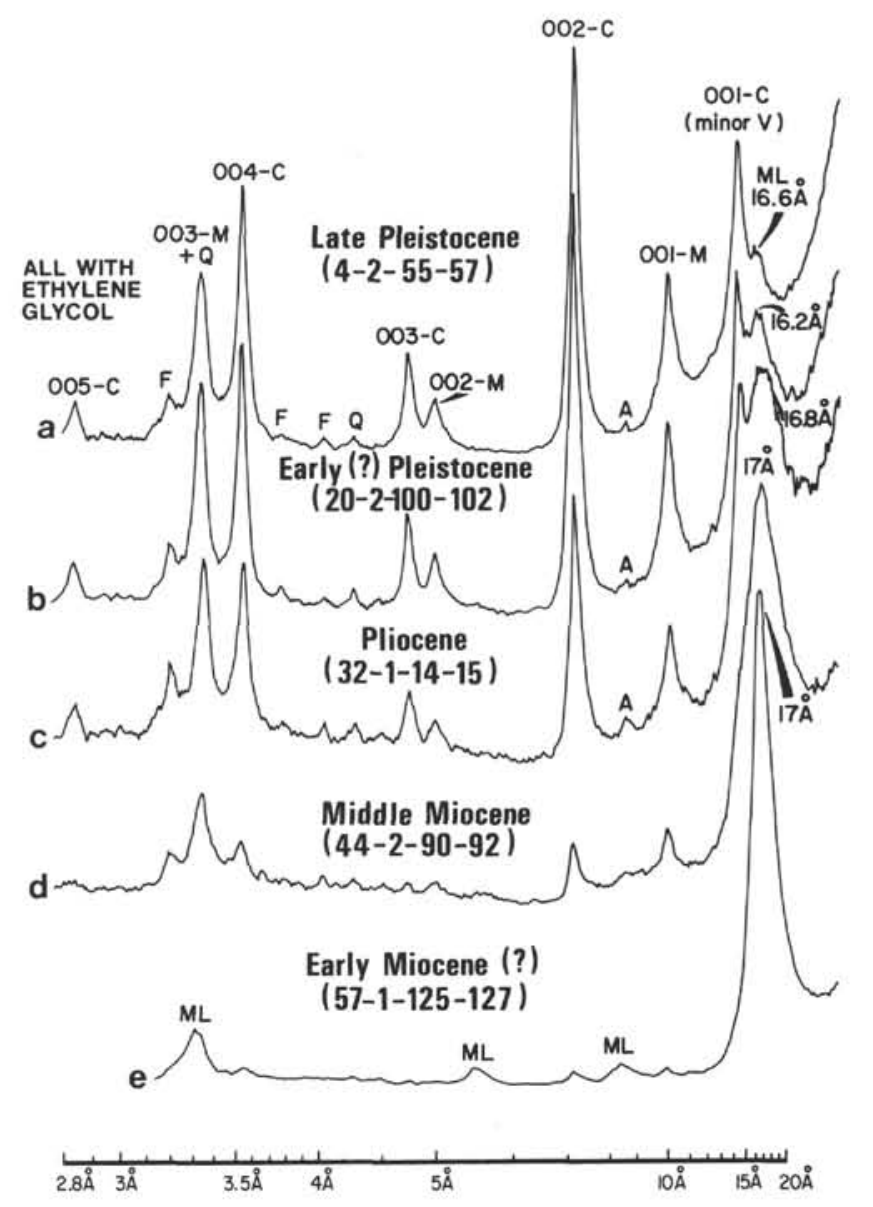

Figure 6. X-ray diffraction patterns to show relative changes in clay mineralogy upward through time at Site 178, Gulf of Alaska.

volcanic activity, either on land or at sea. However, if discrete volcanic ash layers are any indication, volcanic activity actually has increased toward the present, with ash layers being most abundant in the Pliocene and Pleistocene at Site 178. At Site 183 of Leg 19 of DSDP (Scholl et al., 1971), on the Aleutian Abyssal Plain, ever increasing numbers of ash layers upward indicate a major increase in volcanic activity beginning about 3 million years ago in the Pliocene. Therefore, this alternate explanation seems unlikely.

\section{Correlation}

The hard, deformed mudstone below 169 meters at Site 181 is a problem not only because the cause of deformation is unknown, but also because its age is not well established. I wondered if it might have mineralogical characteristics which would permit correlation with the better-dated section at Site 178. First, notice that Quaternary clay suites at Sites 178, 180, and 181 (Figure 2a, Figure 5a-b, Figure $6 \mathrm{a}-\mathrm{b})$ are virtually identical. They are characterized by vermiculitic ML clay which does not expand to $17 \AA$ with 
ethylene glycol, and by clay-size amphibole. Also, the Pliocene sample at Site 178 (Figure 6c) from about 307 meters seems to contain amphibole, though this is obscured somewhat by the possibility of having a weak second-order reflection from the ML clay overlapping the amphibole reflection. On the other hand, the deformed mudstone below 169 meters at Site 181 has no apparent amphibole, and the ML clay expands to $17 \AA$ (Figure $5 \mathrm{c}$ ). One could conclude on mineralogy alone that the mysterious mudstone is not Quaternary, and is older than the analyzed Pliocene sample at Site 178 (Figure 6c), which is in North Pacific Diatom Zone VII (NPD VII), between 2.5 million years and 1.85 to 2.2 million years ago (Schrader, this volume).

However, paleontological data conflict with that conclusion. The hiatus at 169 meters represents a gap of at least 0.5 million years duration (Von Huene, Site 181 summary, this volume). The section below 169 meters is apparently devoid of datable fossils, except down to 186.5 meters; those 17.5 meters contain diatoms from NPD III, which encompasses time from 1.3 to 0.92 million years ago, wholly within the Pleistocene (Schrader, this volume). Yet clay suites from this zone (Table 2, Site 181, samples at $170 \mathrm{~m}$ and $177 \mathrm{~m}$ ) are like the others below 169 meters in lacking amphibole and in having $17-\AA$ ML clay. So, why was clay-size amphibole of presumed terrestrial origin not deposited at Site 181 during the lower part of the Pleistocene and earlier, while it was being deposited at Site 178 which is further from land? And why, when deposition resumed about 0.4 million years ago at Site 181 after the 169-meter hiatus, did amphibole appear? Could clay-size amphibole have been removed from the contorted mudstones below 169 meters by some diagenetic reaction related to deformation? If so, the clay minerals were not obviously affected. I analyzed so few samples from the Alaskan sites that I cannot answer these questions. However, further work is warranted on amphibole distribution, because it certainly is not uniform in time and space, and it may have tectonic, provenance, dispersal, or diagenetic implications.

\section{CONCLUSIONS}

1. Clay mineral suites in Leg 18 mudstones are typical of those encountered previously in Cenozoic sediments of the northeast Pacific. Chlorite, mica, halloysite, and vermiculite are mainly detrital, derived from weathering and erosion of the North American continent. Mixed-layer clay minerals may be derived either from the continent, or from submarine alteration of volcanic debris. Subtle details of mixed-layer mineralogy should serve to distinguish origins.

2. There is no clay mineral evidence to suggest that crumpled mudstones at the continental margin were buried as deep as 3,000 or 4,000 meters. This does not rule out the possibility that such mudstones represent trench sediments which were more deeply buried than at present.

3. Different drainage basins and river systems (e.g., Columbia and Rogue rivers) are delivering different clay mineral suites to the Oregon continental margin. This raises the possibility of using clay minerals for provenance recognition, but not until dispersal mechanisms are better understood.

4. Clay mineral stratigraphy at two sites on oceanic lithospheric plates shows ever increasing content of terrigenous chlorite and mica upward through the sections, relative to mixed-layer clays of probable submarine origin. This suggests ever greater influence of terrestrial sedimentation at these sites as the sites on the oceanic plates moved closer to the continental plate because of destruction of oceanic plates in subduction zones at the continental margin.

\section{ACKNOWLEDGMENTS}

C. Heubach, my colleague at Marathon Oil Company Reserach Center, worked long and hard preparing the samples for X-ray analysis and gathering the X-ray data, for which I express my sincere appreciation. D. B. MacKenzie of Marathon and John Hower of Case Western Reserve University made suggestions for improvement of the manuscript. I am grateful to L. D. Kulm and the staff of DSDP Leg 18 for asking me to study the clay minerals from Leg 18.

\section{REFERENCES}

Bateman, M. K., 1967. Petrology and clay mineralogy of the Tertiary Poul Creek and Yakataga Formations, Cape Yakataga, Alaska. M.S. thesis, Univ. of Iowa, Iowa City, $131 \mathrm{p}$.

Berry, R. W., and Johns, W. D., 1966. Mineralogy of the clay-sized fractions of some North Atlantic-Arctic Ocean bottom sediments. Bull. Geol. Soc. Am. 77, 183.

Biscaye, P. E., 1965. Mineralogy and sedimentation of recent deep-sea clay in the Atlantic Ocean and adjacent seas and oceans. Bull. Geol. Soc. Am. 76, 803.

Burst, J. F., 1969. Diagenesis of Gulf Coast clayey sediments and its possible relation to petroleum migration. Am. Assoc. Petroleum Geologists Bull. 53, 73.

Chichester, F. W., Youngberg, C. T., and Harward, M. E., 1969. Clay mineralogy of soils formed on Mazama pumice. Soil Sci. Soc. Am. Proc. 33, 115.

Duncan, J. R., and Kulm, L. D., 1970. Mineralogy, provenance, and dispersal history of late Quaternary deep-sea sands in Cascadia Basin and Blanco Fracture Zone off Oregon. J. Sed. Petrology. 40, 874.

Duncan, J. R., Kulm, L. D. and Griggs, G. B., 1970. Clay mineral composition of late Pleistocene and Holocene sediments of Cascadia Basin, northeastern Pacific Ocean. J. Geology 78, 213.

Griffin, J. J., Windom, H., and Goldberg, E. D., 1968. The distribution of clay minerals in the World Ocean. Deep-Sea Res. 15, 433.

Hayes, J. B., 1970. Polytypism of chlorite in sedimentary rocks. Clays and Clay Minerals. 18, 285.

Jackson, M. L., 1956. Soil chemical analysis-advanced course. Published by the author, Madison, Wisc., $991 \mathrm{p}$.

Perry, Ed, and Hower, John, 1970. Burial diagenesis of Gulf Coast pelitic sediments. Clays and Clay Minerals. 18, 165.

Pinsak, A. P., and Murray, H. H., 1960. Regional clay mineral patterns in the Gulf of Mexico. Clays and Clay Minerals. 7, 162.

Rex, R. W., 1967. Authigenic silicates formed from basaltic glass by more than 60 million years' contact with sea water, Sylvania Guyot, Marshall Islands. Clays and Clay Minerals. 15, 195. 
1972. Mineralogy of deep-sea sediments from Cretaceous to Holocene [abs.]. Am. Assoc. Petroleum Geologists Bull. 56, 647.

Reynolds, R. C., Jr., and Hower, John, 1970. The nature of interlayering in mixed-layer illite-montmorillonites. Clays and Clay Minerals. 18, 25.

Robertson, R. H. S., 1963. Allophanic soil from Trail Bridge, Oregon, with notes on mosaic growth in clay minerals. Clay Minerals Bull. 5, 237.

Scheidegger, K. F., Kulm, L. D., and Runge, E. J., 1971. Sediment sources and dispersal patterns of Oregon continental shelf sands. J. Sed. Petrology. 41, 1112.

Scholl et al., 1971. Deep Sea Drilling Project: Leg 19. Geotimes. 16 (11), 12.
Siever, Raymond, and Kastner, Miriam, 1967. Mineralogy and petrology of some Mid-Atlantic Ridge sediments. J. Marine Res. 25, 263.

Spigai, J. J., 1971. Marine geology of the continental margin off southern Oregon. Ph.D. thesis, Oregon State Univ., Corvallis, $214 \mathrm{p}$.

Tidball, R. R., 1965. A study of soil development on dated pumice deposits from Mount Mazama, Oregon. Ph.D. thesis, Univ. of California, Berkeley, $251 \mathrm{p}$.

Weaver, C. E., 1958. The effects and geologic significance of potassium "fixation" by expandable clay minerals deriv ed from muscovite, biotite, chlorite, and volcanic material. Am. Mineralogist. 43, 839. 